\title{
Observation of predation of the giant fishing spider Ancylometes rufus (Walckenaer, 1837) (Araneae, Ctenidae) on Dendropsophus melanargyreus Cope, 1877 (Anura, Hylidae)
}

\author{
Mário Ribeiro Moura ${ }^{1,2,3}$ \& Leonardo Pimenta Azevedo ${ }^{2}$ \\ ${ }^{1}$ Ecos Biota Consultoria Ambiental, Rua Senador Vaz de Melo, 60/40, CEP 36570-000, Viçosa, MG, Brazil \\ ${ }^{2}$ Museu de Zoologia João Moojen, Departamento de Biologia Animal, \\ Universidade Federal de Viçosa - UFV, Vila Gianetti, 32, CEP 36570-000, Viçosa, MG, Brazil \\ ${ }^{3}$ Corresponding author: Mário Ribeiro Moura, e-mail: mario.moura@ecosbiota.com.br
}

MOURA, M.R. \& AZEVEDO, L.P. Observation of predation of the giant fishing spider Ancylometes rufus (Walckenaer, 1837) (Araneae, Ctenidae) on Dendropsophus melanargyreus Cope, 1877 (Anura, Hylidae). Biota Neotrop. 11(4): http://www.biotaneotropica.org.br/v11n4/en/abstract?short-communication+bn00211042011.

\begin{abstract}
We report here an observation of predation of the giant spider Ancylometes rufus on the tree frog Dendropsophus melanargyreus in a southern region of Amazonia Forest. We also reviewed the available literature on predation of this spider species on vertebrates.

Keywords: natural history, tree frog, Amazon, Mato Grosso.
\end{abstract}

MOURA, M.R. \& AZEVEDO, L.P. Observação de predação da aranha pescadora Ancylometes rufus (Walckenaer, 1837) (Araneae, Ctenidae) sobre Dendropsophus melanargyreus Cope, 1877 (Anura, Hylidae). Biota Neotrop. 11(4): http://www.biotaneotropica.org.br/v11n4/pt/abstract?short-communication+bn00211042011.

Resumo: Nós reportamos aqui uma observação de predação da aranha pescadora Ancylometes rufus sobre a perereca Dendropsophus melanargyreus na região sul da floresta Amazônica. Nós também revisamos os dados de literatura sobre os eventos de predação envolvendo essa espécie de aranha e outros vertebrados.

Palavras-chave: história natural, perereca, Amazônia, Mato Grosso. 


\section{Introduction}

Many species of invertebrates are known to prey on amphibians (Toledo 2005). Among the most important predators are leeches, crabs and crayfish, amblypygids, caddisfly larvae, dragonfly naiads, heteropterans and spiders (Wells 2007). However, the predation of post-metamorphic anurans is still insufficiently documented (Pombal-Jr 2007), often based on casual observation of single events (Menin et al. 2005, Toledo 2005).

Ancylometes rufus (Walckenaer, 1837) is a large sized fishing spider distributed throughout the rainforests of the Amazon basin and the Atlantic coast of Brazil (Höfer \& Metzner 2011). This species forages mainly on the ground, where it feeds mostly on arthropods (Höfer \& Brescovit 2000, Gasnier et al. 2002). Although A. rufus can occur far from water bodies, it is much more abundant close to aquatic environments, which offer a large availability of food, and an additional escape route, allowing the spider to dive to escape from predators (Azevedo 2000, Höfer \& Brescovit 2000, Gasnier et al. 2009).

This spider is known to prey on anurans, tadpoles and fishes (Azevedo 2000, Azevedo \& Smith 2004), although few published records with identified prey species were found. Among vertebrates included in the diet of $A$. rufus, amphibians are the group cited in most of the reports. Herein, we report a predation event of Dendropsophus melanargyreus (Cope, 1877) by A. rufus from southwestern Amazonia. This anuran is a small sized tree frog with a wide distribution in South America, from Surinam and French Guiana, through north and central Brazil to western Bolivia and northeastern Paraguay (Silva et al. 2010, Frost 2011).

\section{Material and Methods}

On 4 August 2010, an anuran survey was conducted in an area of tropical semideciduous forest in southwestern Amazon forest
(13 $42^{\circ}$ '51' S and 60² $21^{\prime} 48^{\prime \prime}$ W, datum WGS1984, 215 m elevation), at the municipality of Comodoro, state of Mato Grosso, Brazil. The observation reported here was made during active searches performed from sunset to approximately 22:00 hours, using linear transects within the forest and near aquatic environments.

Voucher specimens are housed in the invertebrate collection of Museu de Zoologia João Moojen (Curator Renato Neves Feio), Universidade Federal de Viçosa, municipality of Viçosa, Minas Gerais (Ancylometes rufus, MZUFV 239) and in the herpetological collection of Museu de Ciências Naturais (Curator Luciana Barreto Nascimento), Pontifícia Universidade Católica de Minas Gerais, Belo Horizonte (Dendropsophus melanargyreus, MCNA 14550).

\section{Results and Discussion}

At approximately 20:00 hours, a male of A. rufus $(21.5 \mathrm{~mm}$ total body length) was observed (by MRM) predating an adult D. melanargyreus (40.9 mm snout-vent length) under a dry leaf (Figure 1), one $\mathrm{m}$ from the bank of a stream. The observation lasted at least five minutes, and during this time the spider had already captured the tree frog with the aid of its pedipalps, having its right chelicerae claw inserted near the prey's left eye. At the beginning of the observation, the tree frog was attempting to pull back, away from the predator, with the help of its hind legs. Subsequently, the prey was subdued and immobilized by the spider. At this moment, in an attempt of the observer to capture the specimens, the spider dropped its prey and tried to escape.

Although predation on frogs is most commonly observed during their reproductive season (Toledo 2005), no species was in calling activity during the performed survey (dry season). The locality, close to a stream, was relatively humid even in that period of the year, allowing the presence of foraging frogs. In an investigation of A. rufus in central Amazonia, Azevedo (2000) described that during the wet season, when the availability of food is likely to be larger,

Table 1. Literature review of identified vertebrate species preyed by Ancylometes rufus.

\begin{tabular}{|c|c|c|c|c|}
\hline Vertebrate prey & Habitat & $\begin{array}{l}\text { Prey size } \\
(\mathbf{m m})\end{array}$ & $\begin{array}{c}\text { Predator size } \\
\quad(\mathbf{m m})\end{array}$ & Reference \\
\hline \multicolumn{5}{|l|}{ AMPHIBIA } \\
\hline \multicolumn{5}{|l|}{ Brachycephalidae } \\
\hline Ischnocnema ramagii & A & 21.1 & 20.1 & $\begin{array}{l}\text { De-Carvalho et al. (2010), De-Carvalho } \\
\text { (unpublished data) }\end{array}$ \\
\hline \multicolumn{5}{|l|}{ Bufonidae } \\
\hline Dendrophryniscus minutus & A & 22.0 & 30.0 & Menin et al. (2005) \\
\hline Dendrophryniscus minutus & - & 15.8 & 9.0 & Pazin (2006) \\
\hline \multicolumn{5}{|l|}{ Hylidae } \\
\hline Dendropsophus melanargyreus & A & 40.9 & 21.5 & This study \\
\hline Dendropsophus minutus & $\mathrm{B}$ & 21.0 & 30.0 & Bernarde et al. (1999) ${ }^{1}$ \\
\hline Dendropsophus minutus & B & 22.0 & 26.1 & Menin et al. (2005) \\
\hline Dendropsophus minutus & $\mathrm{B}$ & 24.5 & 31.0 & Menin et al. (2005) \\
\hline Dendropsophus sarayacuensis & $\mathrm{A}$ & 15.0 & 9.32 & Rodrigues \& Arruda (2007) \\
\hline Hypsiboas geographicus & $\mathrm{B}$ & 50.0 & - & Menin et al. (2005), Lima et al. (2006) \\
\hline Scinax alter & $\mathrm{C}$ & 27.3 & 23.0 & Prado \& Borgo (2003) \\
\hline \multicolumn{5}{|l|}{ Leptodactylidae } \\
\hline Adenomera andreae & A & 24.0 & 30.0 & Menin et al. (2005) \\
\hline \multicolumn{5}{|l|}{ REPTILIA } \\
\hline \multicolumn{5}{|l|}{ Gymnophthalmidae } \\
\hline Arthrosaura reticulata & $\mathrm{A}$ & 37.8 & 32.9 & Waldez \& Lima (2006) \\
\hline
\end{tabular}

Habitat type where predation was observed: $\mathrm{A}=$ ground surface; $\mathrm{B}=$ on leaf over a water surface; $\mathrm{C}=$ on aquatic vegetation. ${ }^{1}:$ Ancylometes rufus treated as A. gigas (synonym) 


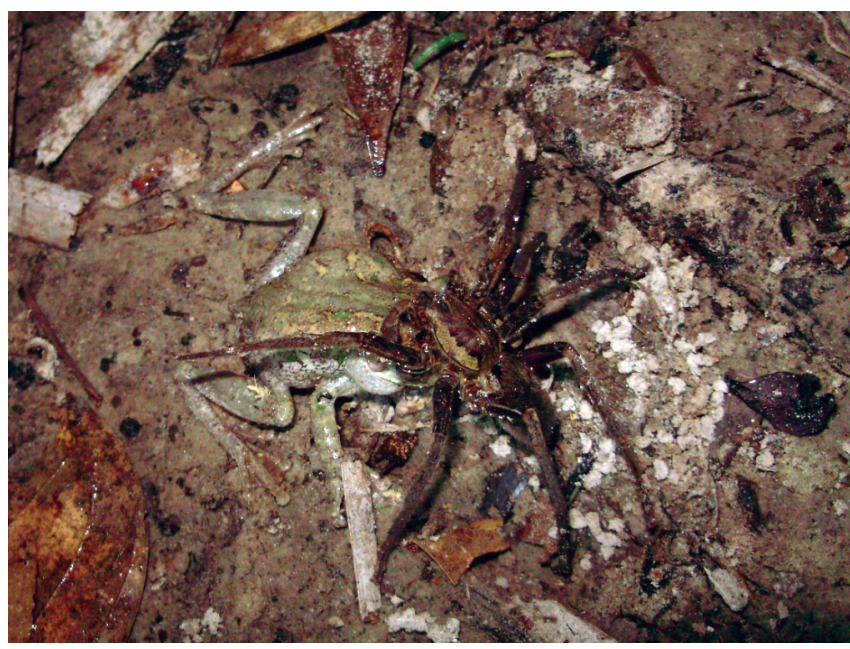

Figure 1. Adult male Ancylometes rufus (21.5 mm total body length) predating an adult Dendropsophus melanargyreus (40.9 mm snout-vent length).

A. rufus foraged preferentially at pools or ponds, apparently in search of prey such as small fish, tadpoles and frogs. In the dry season, spiders returned to the stream margins, where it is probably safer than in temporary pools, but more difficult to capture prey (Azevedo 2000). As our observation was made during the dry season and the predation place was close to a stream, it is in agreement with the reported migration behavior of $A$. rufus.

Records of predation of invertebrates on vertebrates are relatively scarce, because they usually need direct observation, whereas in vertebrates, prey spectrum can be accessed by analyzing the stomach contents (Pombal-Jr 2007). In a review of anurans as prey of invertebrates, Toledo (2005) found 68 reports, from which approximately $48 \%$ had spiders as predators, in particular Pisauridae and Ctenidae. There are at least 12 published records of nine species of vertebrates that have been preyed upon by A. rufus (Table 1). In general, the vertebrate prey of $A$. rufus have about $70-120 \%$ the size of their predator. In the present record, the relation prey-predator size is more than $190 \%$, the tree frog being almost twice the size of the spider.

\section{Acknowledgements}

We thank Hubert Höfer and Thierry R. Gasnier for provision of references. The two anonymous referees by valuable suggestions on the manuscript. Henrique Caldeira Costa for English review. Instituto Brasileiro do Meio Ambiente e dos Recursos Naturais Renováveis (IBAMA) for collection permit (IBAMA \# -122/2010), and BIOCEV Serviços de Meio Ambiente Ltda. for financial and field support.

\section{References}

AZEVEDO, C.S. 2000. Ecologia de Ancylometes gigas (Pickard-Cambridge, 1897) (Araneae: Pisauridae), uma aranha errante que vive próxima a corpos de água em uma floresta tropical úmida. Dissertação de Mestrado, Universidade do Amazonas, Instituto Nacional de Pesquisas da Amazônia, Manaus.
AZEVEDO, C.S. \& SMITH, M. 2004. Araneofauna na região do Seringalzinho. In Janelas para Biodiversidade no Parque Nacional do Jáu (S.H. Borges, S. Iwanaga, C.C. Durigan\& M.R. Pinheiro, eds.). Fundação Vitória Amazônica, Manaus, p.135-142.

BERNARDE, P.S., SOUZA, M.B. \& KOKUBUM, M.C.N. 1999. Predation Hyla minuta Peters, 1872 (Anura, Hylidae) by Ancylometes spp. (Araneae, Pisauridae). Biociências 7(1):199-203

DE-CARVALHO, C.B., FREITAS, E.B., SANTOS, R.A., GUEIROS, F.B., SANTOS, R.V.S. \& FARIA, R.G. 2010. Ischnocnema ramagii (Paraiba Robber Frog). Predation. Herpetol. Rev. 41(3):336-337.

FROST, D.R. 2011. Amphibian Species of the World: an Online reference. Version 5.5. Eletronic Database accessible at: http://research.amnh.org/ herpetology/amphibia/index.php (last access 18/08/2011).

GASNIER, T.R., AZEVEDO, C.S., TORRES-SANCHEZ, M.P. \& HÖFER, H. 2002. Adult size of eight hunting spider species in central Amazonia: temporal variations and sexual dimorphisms. J. Arachn. 30(1):146154. http://dx.doi.org/10.1636/0161-8202(2002)030[0146:ASOEHS 12.0.CO;2

GASNIER, T.R., HÖFER, H., TORRES-SANCHEZ, M.P. \& AZEVEDO, C.S. 2009. História natural de algumas espécies de aranhas das famílias Ctenidae e Lycosidae na Reserva Ducke: bases para um modelo integrado de coexistência. In A fauna de Artrópodes da Reserva Florestal Ducke: estado atual do conhecimento taxonômico e biológico (C.R.V. Fonseca; C. Magalhães; J.A. Rafael; E. Franklin, eds.).Instituto Nacional de Pesquisas da Amazônia - INPA, Manaus, p.223-230.

HÖFER, H. \& METZNER, H. 2011. Ancylometes. http://www.ancylometes. de (last access 18/08/2011).

HÖFER, H. \& BRESCOVIT, A.D. 2000. A revision of the Neotropical spider genus Ancylometes Bertkau (Araneae: Pisauridae). Insect Syst. Evol. 31:323-360. http://dx.doi.org/10.1163/187631200X00075

LIMA, A.P., MAGNUSSON, W.E., MENIN, M., ERDTMANN, L.K., RODRIGUES, D.J., KELLER, C. \& HÖDL, W. 2006. Guia de sapos da Reserva Adolpho Ducke, Amazônia Central. Áttema Design Editorial, Manaus.

MENIN, M., RODRIGUES, D.J. \& AZEVEDO, C.S. 2005. Predation on amphibians by spiders (Arachnida, Aranae) in the Neotropical region. Phyllomedusa 4(1):39-47.

PAZIN, V.F.V. 2006. Dendrophryniscus minutus (Amazonian tiny tree toad). Predation. Herpetol. Rev. 37(3):336.

POMBAL-JR, J.P. 2007. Notas sobre predação em uma taxocenose de anfíbios anuros no sudeste do Brasil. Rev. Bras. Zool. 24(3):841-843.

PRADO, G.M. \& BORGO, J.H. 2003. Scinax alter (NCN). Predation. Herpetol. Rev. 34(3):238-39.

RODRIGUES, D.J. \& ARRUDA, R. 2007. Dendropsophus sarayacuensis (Shreve's Sarayacu Treefrog). Predation. Herpetol. Rev. 38(4):437.

SILVA, F.R., PRADO, V.H.M. \& ROSSA-FERES, D.C. 2010. Amphibia, Anura, Hylidae, Dendropsophus melanargyreus (Cope, 1887): Distribution extension, new state record and geographic distribution map. Check List 6(3):402-404.

TOLEDO, L.F. 2005. Predation of juvenile and adult anurans by invertebrates: current knowledge and perspectives. Herpetol. Rev. 36(4):395-400.

WALDEZ, F. \& LIMA, M.M. 2006. Arthrosaura reticulata (reticulated creek lizard). Predation. Herpetol. Rev. 37(4):462.

WELLS, K.D. 2007. The ecology and behavior of amphibians. The University of Chicago Press, Chicago. 
